\title{
Real-world validation of the 2017 McDonald criteria for pediatric MS
}

Yu Yi M. Wong, MD, C. Louk de Mol, BSc, Roos M. van der Vuurst de Vries, MD, E. Daniëlle van Pelt, MD, PhD, Immy A. Ketelslegers, MD, PhD, Coriene E. Catsman-Berrevoets, MD, PhD, Rinze F. Neuteboom, MD, PhD,* and Rogier Q. Hintzen, MD, PhD*, On behalf of the Dutch pediatric MS and ADEM study group

Neurol Neuroimmunol Neuroinflamm 2019;6:e528. doi:10.1212/NXI.0000000000000528

\section{Abstract}

\section{Objective}

To compare the diagnostic accuracy of the McDonald 2017 vs the McDonald 2010 criteria to predict a second attack of MS (clinically definite MS [CDMS]) at the first attack of acquired demyelinating syndromes (ADS).

\section{Methods}

One hundred sixty-four children (aged $<18$ years) with an incident attack of ADS were included in a prospective multicenter study between June 2006 and December 2016. Brain (and spinal if available) MRI was performed $\leq 3$ months after symptom onset. Sensitivity, specificity, positive predictive value, negative predictive value, and accuracy were compared at baseline between the 2010 and 2017 criteria.

\section{Results}

Among the 164 patients, 110 patients (67\%) presented without encephalopathy (ADS-, female 63\%; median age 14.8 years, IQR 11.3-16.1years) and 54 (33\%) with encephalopathy (acute disseminated encephalomyelitis [ADEM], female 52\%; median age 4.0 years, IQR 2.6-6.1 years). Of the $110 \mathrm{ADS}-$ patients, $52(47 \%)$ were diagnosed with CDMS within a median follow-up of 4.5 years (IQR 2.6-6.7 years). The sensitivity was higher for the 2017 criteria than for the 2010 criteria ( $83 \%$; 95\% CI 67-92, vs 49\%; 95\% CI 33-65; $p<0.001$ ), but the specificity was lower (73\%; 95\% CI 59-84 vs 87\%; 95\% CI 74-94, $p=0.02)$. At baseline, 48 patients fulfilled the 2017 criteria compared with 27 patients when using the 2010 criteria. The results for children aged $<12$ years without encephalopathy were similar. In patients with ADEM, $8 \%$ fulfilled the 2010 criteria and $10 \%$ the 2017 criteria at baseline but no patient fulfilled the criteria for CDMS.

\section{Conclusions}

The McDonald 2017 criteria are more sensitive than the McDonald 2010 criteria for predicting CDMS at baseline. These criteria can also be applied in children aged $<12$ years without encephalopathy but not in children with ADEM.

\section{Classification of evidence}

This study provides Class II evidence that in children with ADS, the $2017 \mathrm{McD}$ onald criteria are more sensitive but less specific than the $2010 \mathrm{McD}$ onald criteria for predicting CDMS.
Correspondence

Dr. Hintzen

r.hintzen@erasmusmc.nl $\rightarrow$ Class of Evidence

Criteria for rating

therapeutic and diagnostic studies

NPub.org/coe

\footnotetext{
*Joint senior authors.

From the Department of Neurology (Y.Y.M.W., C.L.d.M., R.M.v.d.V.d.V., E.D.v.P., I.A.K., R.Q.H.), MS Centre ErasMS, Erasmus MC, Rotterdam, The Netherlands; and Department of Pediatric Neurology (C.E.C.-B., R.F.N.), Erasmus MC, Rotterdam, The Netherlands.

Funding information and disclosures are provided at the end of the article. Full disclosure form information provided by the authors is available with the full text of this article at Neurology.org/NN.

The Article Processing Charge was funded by the authors.

This is an open access article distributed under the terms of the Creative Commons Attribution-NonCommercial-NoDerivatives License 4.0 (CC BY-NC-ND), which permits downloading and sharing the work provided it is properly cited. The work cannot be changed in any way or used commercially without permission from the journal.
} 


\section{Glossary}

ADEM = acute disseminated encephalomyelitis; ADS = acquired demyelinating syndrome; CDMS = clinically definite MS; DIS = dissemination in space; DIT = dissemination in time; DMT = disease modifying treatment; FLAIR = fluid-attenuated inversion recovery; FU = follow-up; HR = hazard ratio; IPMSSG = International Pediatric MS Study Group; NPV = negative predictive value; $\mathbf{O C B}=$ oligoclonal band; $\mathbf{P P V}=$ positive predictive value .

MS is a chronic demyelinating disorder of the CNS. ${ }^{1} \mathrm{Up}$ to $10 \%$ of all patients with MS have their first symptoms before age 18 years. ${ }^{2,3}$ Recently, the international panel on diagnosis of MS proposed the McDonald 2017 criteria by reviewing and revising the previous $2010 \mathrm{McDonald}$ criteria. ${ }^{4,5}$ These revised criteria include modifications to facilitate earlier MS diagnosis while attempting to preserve the diagnostic accuracy of the criteria. ${ }^{5}$ Important modifications included reintroducing CSF oligoclonal bands (OCBs) into the criteria as a substitute for dissemination in time (DIT) and allowing symptomatic lesions to contribute to dissemination in space (DIS) and DIT. Furthermore, cortical lesions have been combined with the juxtacortical lesion component to demonstrate DIS.

The applicability of the adult McDonald 2010 criteria in children was supported by several studies. ${ }^{6-12}$ These criteria were implemented in the revised 2012 diagnostic criteria for children with acquired demyelinating syndromes (ADS) proposed by the International Pediatric MS Study Group (IPMSSG). ${ }^{13}$ ADS encompass the first attack of demyelination in the CNS. ${ }^{13,14}$ According to the IPMSSG criteria, MS diagnosis based on the first baseline MRI in children with a first attack should be performed with caution for children aged $<12$ years and patients presenting with acute disseminated encephalomyelitis (ADEM) because of a lower specificity and sensitivity of the McDonald 2010 criteria in these groups. $^{13}$

A Canadian study reported that the revised McDonald 2017 criteria apply well in children with a first attack of ADS across the age span. ${ }^{15}$ Validation of these criteria in different study populations is imperative because of the long-term administration of disease-modifying treatment (DMT) after MS diagnosis. Overtreatment in patients must be prevented, as well as undertreatment, because of delayed diagnosis. Early and accurate identification of patients with MS is therefore essential.

We aimed at evaluating the diagnostic accuracy of the revised 2017 MS criteria in children with ADS at the time of the first presentation. Extra attention is paid to children younger than age of 12 years and to patients presenting with ADEM.

\section{Methods}

\section{Patients and design}

Children younger than 18 years with a first attack of demyelination were consecutively included in the nationwide, multicenter, and prospective study for children with ADS between June 2006 and December 2016 (PROUD-kids study). ${ }^{16,17}$ Patients were assessed at baseline and were prospectively followed up. MRI was performed within 3 months after symptom onset as part of a routine diagnostic process to rule out alternative diagnoses. Patients with alternative nondemyelinating disorders were excluded from our study. All patients had a follow-up (FU) duration of at least 1 year because the interval between the first and second attacks in pediatric MS is typically less than 1 year. ${ }^{18-21}$

Patients were included for analysis when presenting with ADS without (ADS-) and with encephalopathy (ADEM). ${ }^{13}$ Patients with neuromyelitis optica spectrum disorders or with relapsing disease other than MS were excluded from analyses (e.g., patients presenting with relapsing anti-MOG antibody related disorders) because there is emerging evidence that these patients have a distinct clinical phenotype. ${ }^{22,23}$

\section{Standard protocol approvals and patient consents}

The PROUD-kids study protocol was approved by the Ethics Committee Erasmus MC, Rotterdam, and by the other participating centers in the Netherlands. Written informed consent was obtained from all patients and/or their families.

\section{Definitions}

ADS in children encompass the first attack of demyelination in the CNS, including patients presenting with (ADS+) and without encephalopathy (ADS-). ADEM was defined as a polyfocal onset with encephalopathy (ADS+). ${ }^{13}$ Clinically definite MS (CDMS) was defined as a second attack of MS, with 2 nonencephalopathic confirmed attacks with clinical evidence of 2 separate lesions. ${ }^{13}$ ADS- patients who remained monophasic were defined as monophasic ADS- ${ }^{13}$ Patients were reassessed annually. The patients were instructed to contact the outpatient clinic if new symptoms occurred to be clinically assessed. A relapse was defined as new neurologic deficits or subacute worsening of existing symptoms after 30 days of improvement or stable disease, without evidence of an alternative diagnosis. ${ }^{24}$

\section{Procedures}

Brain and spine MRI scans were performed at 1.5 Tesla scanners. Available T1-, axial T2-, axial and/or sagittal fluidattenuated inversion recovery (FLAIR)-, and T1-weighted images with gadolinium administration were evaluated centrally. The MRI scan closest to the date of symptom onset was evaluated as the baseline scan. 
For DIS, all baseline MRI scans were scored using the McDonald 2010 criteria and the modified components as described in the revised McDonald 2017 criteria for the first MRI scan (table 1). MRI techniques, such as double inversion recovery, that are required to reliably demonstrate cortical lesions were not part of the routine MRI protocol. Therefore, the cortical lesion component was not taken into account in our analyses. If a spinal MRI was performed within 30 days after or before brain MRI, this scan was taken into account in scoring the DIS components. For DIT, all MRI scans with post-gadolinium T1 images were used; or scans that did not have gadolinium administered, but did not show any FLAIR/T2 hyperintense lesions either. CSF analyses for OCBs were performed in local laboratories using isoelectric focusing. ${ }^{25}$ OCB status was considered positive if there were $\geq 2$ unique bands in CSF compared with serum.

\section{Rationale}

We set out to analyze our data in a manner that is representative for clinical practice. As acknowledged by the International Panel on Diagnosis of MS, spinal cord MRI and/or lumbar puncture was not performed in every case depending on clinical presentation and was left to the decision of the local treating physician. ${ }^{5}$ We did not exclude patients without a spinal cord MRI or lumbar puncture because this would probably introduce selection bias in our study.

DIS was based on 3 parameters (periventricular, juxtacortical, and infratentorial) or 4 including spinal localization if a spinal MRI was performed. We allowed OCB status to contribute to the fulfillment of DIT 2017 in patients with no gadolinium enhancement.

\section{Statistical analyses}

For statistical analyses, we used SPSS software, version 24.0 (SPSS Inc.) and GraphPad Prism5. CDMS diagnosis was used as an endpoint for all following analyses. For group comparisons, the $\chi^{2}$ test and Fisher exact test were used for categorical data. The Mann-Whitney $U$ test was used for continuous data.

\section{Diagnostic performance and accuracy}

Patients fulfilling the diagnostic criteria at the time of the first attack with a subsequent diagnosis of CDMS during FU were considered true positives. False positives did fulfill the diagnostic criteria for MS at baseline MRI but were not diagnosed with CDMS during FU. Patients who did not fulfill the diagnostic criteria at baseline MRI and who were not diagnosed with CDMS during FU were considered true negatives. False negatives were patients who did not fulfill the diagnostic criteria on baseline MRI but were diagnosed with CDMS during FU.

Sensitivity, specificity, positive predictive value (PPV), negative predictive value (NPV), and accuracy were calculated, including a $95 \% \mathrm{CI}$.

Comparison between the sensitivity and specificity for the 2010 and 2017 criteria was made using the McNemar test. Kaplan-Meier analysis was used to analyze the time to CDMS diagnosis using the 2010 and 2017 criteria (log-rank test). Patients who did not meet the criteria for CDMS diagnosis during FU were considered censored observations. Cox hazard regression analyses were performed to calculate hazard ratios (HRs) for time to MS diagnosis based on the McDonald 2010 criteria (applied at baseline), McDonald 2017

Table 1 Baseline MRI criteria for MS diagnosis derived from the McDonald 2010 and revised 2017 criteria

\begin{tabular}{|c|c|}
\hline McDonald 2010 criteria for baseline MRI & Revised McDonald 2017 criteria for baseline MRI \\
\hline DIS & DIS \\
\hline At least 2 out of 4 of: & At least 2 out of 4 of: \\
\hline$\geq 1$ periventricular lesion & $\geq 1$ periventricular lesion \\
\hline$\geq 1$ juxtacortical lesion & $\geq 1$ juxtacortical or cortical lesion \\
\hline$\geq 1$ infratentorial lesion & $\geq 1$ infratentorial lesion \\
\hline $\begin{array}{l}\geq 1 \text { spinal cord lesion (symptomatic brainstem } \\
\text { syndromes or spinal cord lesions are excluded) }\end{array}$ & $\begin{array}{l}\geq 1 \text { spinal cord lesion (asymptomatic and symptomatic brainstem syndromes or spinal } \\
\text { cord lesions are included) }\end{array}$ \\
\hline McDonald 2010 criteria for baseline MRI & Revised McDonald 2017 criteria for baseline MRI \\
\hline DIT & DIT \\
\hline \multirow[t]{3}{*}{$\begin{array}{l}\text { Simultaneous presence of asymptomatic } \\
\text { gadolinium-enhancing lesions }\end{array}$} & At least 1: \\
\hline & Simultaneous presence of asymptomatic or symptomatic gadolinium-enhancing lesions \\
\hline & Presence of unique CSF oligoclonal bands compared with serum as a substitute for DIT \\
\hline
\end{tabular}

Abbreviations: DIS = dissemination in space; DIT = dissemination in time. 
criteria (applied at baseline), and CDMS diagnosis. $p$ Values < 0.05 were considered statistically significant.

\section{Data availability statement}

The raw data used in this article could be shared in an anonymized format by request from a qualified investigator.

\section{Results}

\section{Patient characteristics}

The inclusion and exclusion process of eligible ADS children is displayed in figure 1. Among the 164 included patients with a first demyelinating event, 54 patients (33\%) presented with encephalopathy (ADS+) and were diagnosed with ADEM. The other 110 (67\%) were ADS- at the time of inclusion. Of these, 52/110 (47\%) were diagnosed with CDMS during FU (median FU time, 4.5 years, interquartile range (IQR) 2.6-6.6 years). The median time to CDMS diagnosis was 10.2 months (IQR 3.8-20.7 months). None of the patients with ADEM had a second attack within a median FU of 5.1 years (IQR 2.7-7.8). Patient characteristics and statistical comparisons between monophasic ADS- and CDMS are displayed in table 2.

\section{DIS and DIT performance on baseline MRI}

All test characteristics of analyses with and without children aged $<12$ years are presented in table 3 .

\section{Dissemination in space}

Hundred and ten ADS- patients were included for this analysis, of whom 52 were diagnosed with CDMS during FU (47\%). Spinal MRI was included when available. The 2010 DIS criteria were fulfilled in 54 patients (49\%). Of these, 41 were diagnosed with CDMS (76\%). Additional 16 patients fulfilled the 2017 DIS criteria $(n=70,64 \%)$, and 48 of these 70 patients were diagnosed with CDMS (69\%). The 2017 DIS criteria yield an increase in sensitivity of $13 \%$ compared with the 2010 criteria $(p=0.1)$ and a loss in specificity of $16 \%(p=0.008)$.

Figure 1 Flow chart for patient inclusion

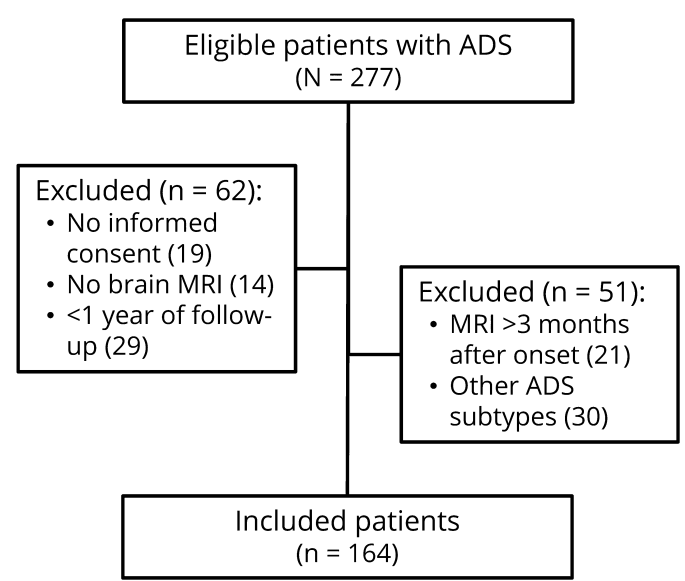

A subanalysis evaluating the fulfillment of DIS in patients who had T1 images with gadolinium administration $(\mathrm{n}=93)$ yielded no difference in the results.

Of the 110 ADS- patients, 61 patients (55\%) had spinal cord imaging, and spinal lesions were detected in 45/61 scans (74\%). In a subgroup analysis, we included only patients who underwent a spinal scan. The test characteristics of DIS were comparable to the results mentioned earlier.

\section{Dissemination in time}

To evaluate the DIT for both criteria, we selected ADSpatients who had $\mathrm{T} 1$ images with gadolinium administration $(\mathrm{n}=93)$. Of these patients, 41 were diagnosed with CDMS during FU (44\%). The 2010 DIT criteria were fulfilled in 35 patients (38\%). Of these, 23 were diagnosed with CDMS (66\%). Regarding the difference between the symptomatic and asymptomatic lesions for the DIT component, we observed that the 2017 DIT criteria (excluding OCBs) yielded 3 more patients fulfilling the DIT criteria $(n=38,41 \%)$, of whom $26 / 38$ were diagnosed with CDMS (68\%). A major increase in patients fulfilling DIT with the 2017 criteria is caused by allowing OCBs to contribute to DIT when no gadolinium enhancement was present: an additional 20 patients fulfilled 2017 DIT criteria at baseline $(\mathrm{n}=58$ patients, $62 \%)$. Thirtyseven $(64 \%)$ of these 58 patients were diagnosed with CDMS.

The test characteristics for 2010 and 2017 DIT criteria, excluding OCB status, were similar. When adding OCB status, the DIT criteria yield $27 \%$ in sensitivity $(p<0.001)$ but lost $17 \%$ in specificity $(p=0.004)$ (table 3$)$.

\section{McDonald 2010 vs McDonald 2017 criteria}

To evaluate the McDonald 2010 and 2017 criteria, we selected ADS- patients who had T1 images with gadolinium administration $(\mathrm{n}=93)$. The McDonald 2010 DIS + DIT criteria were fulfilled in 27/93 patients at baseline (29\%), of whom 20 were diagnosed with CDMS (74\%) after a median FU of 4.5 years (IQR 2.6-7.1 years).

The McDonald 2017 criteria identified 21 additional patients who fulfilled the criteria at baseline $(n=48,52 \%)$ compared with the 2010 criteria, and 34/48 patients (71\%) were diagnosed with CDMS. The sensitivity was higher in the McDonalds 2017 criteria ( $83 \%$ vs $49 \%$; $p<0.001$ ), and the specificity was lower ( $73 \%$ vs $87 \%$; $p=0.02$ ) (table 3 ).

The 7 patients who caused the loss in specificity were identified (fulfilling the 2017 criteria and not the 2010 criteria at baseline, but not having a second attack during an FU of median 2.7 years [IQR: $1.2-6.5$ years]). New lesions on subsequent MRI were observed in 4 of these 7 patients during FU. The other 3 patients did not undergo a second MRI.

Of the 41 patients diagnosed with CDMS, the McDonald 2010 criteria led to the identification of 20 patients (49\%) at baseline. A second attack occurred in $17 / 20$ patients (85\%) 
Table 2 Patient characteristics

\begin{tabular}{|c|c|c|c|c|c|c|}
\hline & ADS- $(n=110)$ & $\begin{array}{l}\text { Monophasic } \\
\text { ADS- }(n=58)\end{array}$ & $\begin{array}{l}\text { CDMS } \\
(n=52)\end{array}$ & $\begin{array}{l}\text { ADS+ } \\
(n=54)\end{array}$ & All $(n=164)$ & $p$ Value $^{a}$ \\
\hline Sex, female, n (\%) & $69(63)$ & $32(55)$ & $37(71)$ & $28(52)$ & $97(59)$ & 0.11 \\
\hline Age at onset, median (IQR), y & $14.8(11.3-16.1)$ & $13.3(9.1-16.0)$ & $15.4(13.7-16.2)$ & $4.0(2.6-6.1)$ & $12.1(5.1-15.8)$ & $<0.004$ \\
\hline Age $<12$ years, $n(\%)$ & $30(27)$ & $23(40)$ & $7(14)$ & $51(94)$ & $81(49)$ & 0.002 \\
\hline Presenting phenotype, n (\%) & & & & & & 0.001 \\
\hline Optic neuritis & $36(33)$ & $23(40)$ & $13(25)$ & 0 & $36(22)$ & - \\
\hline Transverse myelitis & $18(16)$ & $15(26)$ & $3(6)$ & 0 & $18(11)$ & - \\
\hline Other monofocal ADS- & $25(23)$ & $11(19)$ & $14(27)$ & 0 & $25(15)$ & - \\
\hline Polyfocal ADS- & $31(28)$ & $9(16)$ & $22(42)$ & 0 & $31(19)$ & - \\
\hline Polyfocal ADS with encephalopathy (ADEM) & 0 & 0 & 0 & $54(100)$ & $54(33)$ & - \\
\hline Spinal MRI, n (\%) & $61(56)$ & $34(59)$ & $27(52)$ & $14(26)$ & $75(46)$ & 0.57 \\
\hline Spinal cord lesions present, $n$ (\%) & $45 / 61(74)$ & 23/34 (68) & $22 / 27(82)$ & $11 / 14(79)$ & $56 / 75(75)$ & 0.27 \\
\hline Symptomatic spinal cord lesion, n (\%) & $29 / 45(64)$ & $18 / 23(78)$ & $11 / 22(50 \%)$ & $7 / 11(64 \%)$ & $36 / 56(64)$ & 0.07 \\
\hline Gadolinium administration, n (\%) & $89(81)$ & $48(83)$ & $41(79)$ & $49(91)$ & $138(84)$ & 0.63 \\
\hline Gadolinium enhancement, n (\%) & $38 / 89(43)$ & $12 / 48(25)$ & $26 / 41(63)$ & $8 / 49(16)$ & $46 / 138(33)$ & $<0.001$ \\
\hline OCBs tested, n (\%) & $86 / 110(78)$ & $44 / 58(76)$ & $42 / 52(81)$ & $33 / 54(61)$ & $119(73)$ & 0.65 \\
\hline OCBs present, n (\%) & $54 / 86(49)$ & $17 / 44(39)$ & $37 / 42(88)$ & 1/33 (3) & $55(34)$ & $<0.001$ \\
\hline Time to baseline MRI, median (IQR), wk & $1.6(0.6-3.4)$ & $1.4(0.4-3.1)$ & $2.3(0.8-4.7)$ & $1.4(0.7-2.4)$ & $1.4(0.6-3.1)$ & 0.02 \\
\hline Time to lumbar puncture, median (IQR), wk & $2.5(0.7-9.3)$ & $1.8(0.4-8.4)$ & $3.3(1.0-10.1)$ & $1.1(0.4-2.4)$ & $2.0(0.7-6.5)$ & 0.11 \\
\hline Time to CDMS, median (IQR), mo & $10.2(3.8-20.7)$ & NA & $10.2(3.8-20.7)$ & NA & NA & NA \\
\hline Follow-up time, median (IQR), y & $4.5(2.6-6.7)$ & $3.4(2.1-5.2)$ & $6.0(4.2-7.8)$ & $5.1(2.7-7.8)$ & $4.6(2.6-7.1)$ & $<0.001$ \\
\hline DMT use, $\mathrm{n}(\%)$ & $63 / 110(57)$ & $15 / 58(26)$ & $48 / 52(92)$ & $1 / 54(2)$ & $64(39)$ & $<0.001$ \\
\hline DMT use before CDMS diagnosis, $n$ (\%) & $14 / 63(22)$ & NA & $14 / 48(30)$ & NA & $14(9)$ & NA \\
\hline Presence of MOG antibodies, $n$ (\%) & $5 / 69(7)$ & $5 / 34(15)$ & $0 / 35(0)$ & $16 / 35(46)$ & $21 / 104(20)$ & 0.03 \\
\hline Presence of AQP4 antibodies, $n$ (\%) & $0 / 61(0)$ & $0 / 40(0)$ & $0 / 21(0)$ & $0 / 27(0)$ & $0 / 88(0)$ & NA \\
\hline
\end{tabular}

Abbreviations: $A D E M=$ acute disseminated encephalomyelitis; $A D S=$ acquired demyelinating syndrome; $A Q P 4=$ anti-aquaporin 4; $C D M S=$ clinically definite MS; DMT = disease-modifying treatment; $\mathrm{MOG}=$ anti-myelin oligodendrocyte glycoprotein; $\mathrm{NA}=$ not applicable; $\mathrm{OCB}=$ oligoclonal band.

Patient characteristics for patients with acquired demyelinating syndromes without encephalopathy (ADS-), CDMS, and ADEM (ADS+).

In the Dutch pediatric setting, DMTs are prescribed when the patient fulfills the criteria for MS, either clinically or radiologically.

${ }^{a}$ Comparison between monophasic ADS- and CDMS. Statistical significance $p<0.05$

within 3 years of $\mathrm{FU}$ and in 19/20 (95\%) within 5 years. With the McDonald 2017 criteria, 34/41 (83\%) patients with CDMS were identified at baseline. At 3 and 5 years of FU, 31/34 (91\%) and 33/34 (97\%) had a second attack within 3 and 5 years.

Only 1 patient who fulfilled the 2010 and 2017 diagnostic criteria at baseline did not have a second attack (CDMS) within 5 years of FU, yet this patient showed new MRI lesions on FU scans.

The survival curves for CDMS diagnosis, the McDonald 2010 criteria, and the revised McDonald 2017 criteria on baseline MRI are presented in figure 2. MS diagnosis could be made earlier in patients with ADS using the 2017 than the 2010 criteria. For both criteria, the HRs for the DIS, DIT, and full criteria at baseline are displayed in table 4 .

\section{Contribution of symptomatic enhancing lesions, OCBs, and spinal cord imaging}

As described earlier, the McDonald 2017 criteria identified 21 additional patients $(n=48)$ compared with the 2010 criteria $(\mathrm{n}=27)$.

These 21 patients were identified with the contribution of 2 major changes in the criteria. First, symptomatic lesions can be included to demonstrate DIS and DIT for the McDonald 2017 criteria. This led to 7 more MS diagnoses $(n=34)$ at 
Table 3 Test characteristics of the McDonald 2010 and McDonald 2017 criteria

\begin{tabular}{|c|c|c|c|c|c|c|c|c|}
\hline $\begin{array}{l}\text { Patients with ADS- and CDMS, } \\
\text { excluding ADEM }\end{array}$ & $\begin{array}{l}\text { DIS } 2010 \\
(n=110)\end{array}$ & $\begin{array}{l}\text { DIS } 2017 \\
(n=110)\end{array}$ & $\begin{array}{l}\text { DIT } 2010 \\
(n=93)\end{array}$ & $\begin{array}{l}\text { DIT } 2017 \text { (OCBs } \\
\text { excluded) }(n=93)\end{array}$ & $\begin{array}{l}\text { DIT } 2017 \text { (OCBs } \\
\text { included) }(n=93)\end{array}$ & $\begin{array}{l}\text { McDonald (DIS + } \\
\text { DIT) } 2010(\mathrm{n}=93)\end{array}$ & $\begin{array}{l}\text { McDonald (DIS + DIT) } 2017 \\
\text { (OCBs excluded) }(n=93)\end{array}$ & $\begin{array}{l}\text { McDonald (DIS + DIT) } 2017 \\
\text { (OCBs included) }(n=93)\end{array}$ \\
\hline Sensitivity \% $(95 \% \mathrm{Cl})$ & 79 (65-89) & $92(81-98)$ & $\begin{array}{l}56 \\
(40-71)\end{array}$ & $63(47-77)$ & 90 (76-97) & $49(33-65)$ & $61(45-75)$ & $83(67-92)$ \\
\hline Specificity \% (95\% Cl) & $78(64-87)$ & $62(48-74)$ & $\begin{array}{l}77 \\
(63-87)\end{array}$ & 77 (63-87) & $60(45-73)$ & $87(74-94)$ & $83(69-91)$ & $73(59-84)$ \\
\hline PPV \% (95\% Cl) & $76(62-86)$ & 69 (56-79) & $\begin{array}{l}66 \\
(48-80)\end{array}$ & $68(51-82)$ & $64(50-76)$ & $74(53-88)$ & $74(55-87)$ & $71(56-83)$ \\
\hline NPV \% (95\% Cl) & $80(67-89)$ & 90 (75-97) & $\begin{array}{l}69 \\
(55-80)\end{array}$ & $73(59-84)$ & 89 (72-96) & $68(55-79)$ & $73(60-83)$ & $84(70-93)$ \\
\hline Accuracy \% (95\% Cl) & $78(71-86)$ & $76(69-84)$ & $\begin{array}{l}68 \\
(58-77)\end{array}$ & $71(62-80)$ & $73(64-82)$ & $70(61-79)$ & $73(64-82)$ & $77(69-86)$ \\
\hline $\begin{array}{l}\text { Patients with ADS- and CDMS }<12 \\
\text { years (excluding ADEM) }\end{array}$ & $\mathrm{n}=30$ & $n=30$ & $n=28$ & $n=28$ & $n=28$ & $\mathrm{n}=28$ & $n=28$ & $n=28$ \\
\hline Sensitivity \% (95\% Cl) & 86 (42-99) & $\begin{array}{l}100 \\
(56-100)\end{array}$ & $\begin{array}{l}71 \\
(30-95)\end{array}$ & 71 (30-95) & $100(56-100)$ & $57(20-88)$ & 71 (30-95) & $100(56-100)$ \\
\hline Specificity \% (95\% Cl) & $87(65-97)$ & $78(56-92)$ & $\begin{array}{l}90 \\
(68-98)\end{array}$ & $90(68-98)$ & $81(57-94)$ & $95(74-100)$ & $95(74-100)$ & $91(68-98)$ \\
\hline PPV \% (95\% CI) & $67(31-91)$ & $58(29-84)$ & $\begin{array}{l}71 \\
(30-95)\end{array}$ & $71(30-95)$ & $64(32-88)$ & 80 (30-99) & 83 (37-99) & $78(40-96)$ \\
\hline NPV \% (95\% CI) & $\begin{array}{l}95 \\
(74-100)\end{array}$ & $\begin{array}{l}100 \\
(78-100)\end{array}$ & $\begin{array}{l}90 \\
(68-98)\end{array}$ & $90(68-98)$ & $100(77-100)$ & 87 (65-97) & $91(69-98)$ & $100(79-100)$ \\
\hline Accuracy \% $(95 \% \mathrm{Cl})$ & 87 (75-99) & $83(70-96)$ & $\begin{array}{l}86 \\
(73-99)\end{array}$ & 86 (73-99) & 86 (73-99) & 86 (73-99) & $89(78-100)$ & $93(83-100)$ \\
\hline
\end{tabular}

Abbreviations: $A D E M=$ acute disseminated encephalomyelitis; $A D S=$ acquired demyelinating syndrome; DIS = dissemination in space; DIT = dissemination in time; $C D M S$ = clinically definite MS.

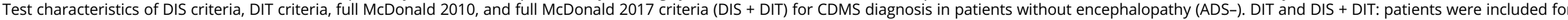

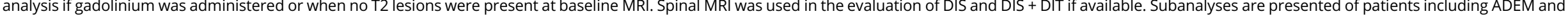
patients younger than 12 years (excluding ADEM). 
Figure 2 Time from incident ADS event to MS diagnosis

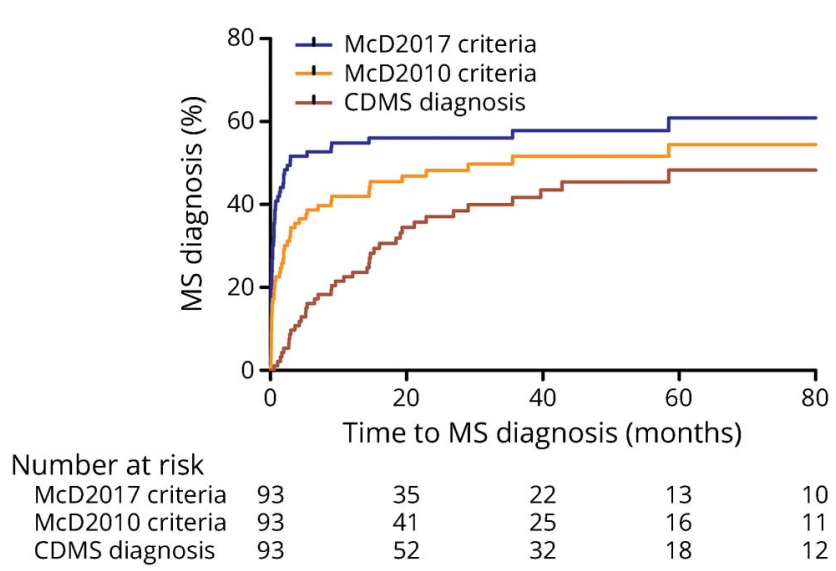

Survival curves for time from incident ADS event to MS diagnosis according to the McDonald 2010 criteria (at baseline), McDonald 2017 criteria (at baseline), and CDMS. ADS = acquired demyelinating syndrome; CDMS = clinically definite multiple sclerosis.

baseline compared with the 2010 criteria $(\mathrm{n}=27)$. Of these 34 patients, 25 were diagnosed with CDMS (74\%).

Second, OCBs are allowed to be taken into account when assessing DIT. This led to the other 14 patients who fulfilled the McDonald 2017 criteria at baseline (total $n=48$ ) and caused the major increase in the sensitivity of the criteria. Among these 48 patients, 34 (71\%) were diagnosed with CDMS.

No additional patients fulfilled the McDonald 2010 criteria depending on spinal imaging. In contrast, the presence of a spinal cord lesion contributed to fulfilling the McDonald 2017 criteria at baseline in 6 patients. Three of these patients were eventually diagnosed with CDMS. Thus, 3/41 (7\%) patients with future CDMS fulfilled the DIS component at baseline by performing spinal cord imaging.

\section{Relevant subgroup analyses}

\section{DMT use before CDMS}

DMTs have the potency to postpone a second attack and could therefore influence CDMS diagnosis. We performed a subgroup analysis after excluding patients who received DMT before CDMS diagnosis (exclusion $\mathrm{n}=12$ ). In the included patients $(n=81)$, test characteristics for the full criteria (DIS + DIT) remained comparable to the total group (including DMT use before CDMS) for both the 2010 (sensitivity $41 \%$ vs 49\%; specificity $87 \%$ for both selections) and 2017 criteria (sensitivity $83 \%$ and specificity $73 \%$ for both selections).

\section{Analysis in ADS- patients aged $<12$ years}

The IPMSSG recommended that the McDonald 2010 criteria at baseline should be used with caution in patients aged $<12$ years. We applied the novel 2017 criteria to the group of patients younger than 12 years only after exclusion of ADEM cases.

Seven of 28 ADS- patients (25\%) were diagnosed with CDMS. Five patients (18\%) fulfilled the baseline criteria for 2010 , and 4 of them (80\%) fulfilled the criteria for CDMS. Nine patients fulfilled the 2017 criteria (32\%), and 7 (78\%) were diagnosed with CDMS.

The test characteristics were even better in children aged $<12$ years than in the total group for both McDonald 2010 criteria (sensitivity $57 \%$ vs $49 \%$; specificity $95 \%$ vs $87 \%$ ) and 2017 criteria (sensitivity $100 \%$ vs $83 \%$; specificity $91 \%$ vs $73 \%$ ).

\section{Analysis in the ADEM subgroup}

Only patients with ADEM are included in this analysis ( $\mathrm{n}=$ 54). DIS was fulfilled for the 2010 criteria and 2017 criteria in 24 (44\%) vs 28 (52\%) patients with ADEM, respectively.

Regarding DIT, 7/49 (14\%) patients with ADEM fulfilled the 2010 DIT criteria and 9/49 (18\%) fulfilled the 2017 DIT criteria, including OCB status. Of note, 4/49 (8\%) patients would have fulfilled the McDonald 2010 criteria and 5/49 (10\%) the McDonald 2017 criteria (gain of 1 patient due to OCBs). None of the patients fulfilled the criteria for CDMS during FU.

\section{Discussion}

We investigated the application of the novel McDonald 2017 criteria for pediatric MS in clinical practice. We show that the McDonald 2017 criteria have a higher sensitivity than the previous 2010 criteria for CDMS diagnosis for pediatric patients $(83 \%$ vs $49 \%, p<0.001)$. However, the specificity was lower $(73 \%$ vs $87 \%, p=0.02)$. Overall, the diagnostic accuracy

Table 4 Hazard ratios for CDMS diagnosis after applying DIS, DIT, and full criteria (DIS + DIT) for McDonald 2010 and 2017 on baseline MRI

\begin{tabular}{lllll}
\hline & McDonald 2010 & p Value & McDonald 2017 & $p$ Value \\
\hline DIS (n=110) & HR 5.8 (95\% Cl 3.0-11.4) & $p<0.001$ & HR 11.3 (95\% Cl 4.0-31.6) & $p<0.001$ \\
\hline DIT (n=93) & HR 2.9 (95\% Cl 1.5-5.4) & $p=0.001$ & HR 8.3 $(95 \% \mathrm{Cl} 3.0-23.4)$ & $p<0.001$ \\
\hline DIS + DIT (n=93) & HR 3.1 (95\% Cl 1.7-5.8) & $p<0.001$ & HR 8.5 (95\% Cl 3.5-20.4) & $p<0.001$ \\
\hline
\end{tabular}

Abbreviations: CDMS = clinically definite MS; DIS = dissemination in space; DIT = dissemination in time; HR = hazard ratio. 
of the 2017 criteria was higher than that for the 2010 criteria ( $77 \%$ vs $70 \%$ ). The revised criteria are easier to apply than the McDonald 2010 criteria, mainly because of the major change of accepting all lesions to contribute to DIS and DIT, without taking the clinical symptoms into account. Moreover, we show that the 2017 McDonald criteria lead to more MS diagnosis at baseline; therefore, MS diagnosis can be made earlier using the 2017 criteria.

A high sensitivity is important to start DMT as soon as possible, ${ }^{26}$ which might lead to overtreatment in the group of patients who have a less active clinical disease course. Our main findings are supported by a recent extensive study in a cohort of patients with ADS that also included evaluation of the applicability of the McDonald 2017 criteria. ${ }^{15}$ We validate their finding that the sensitivity is increased and specificity is decreased mainly by including OCB status into the 2017 criteria. However, the specificity of the McDonald 2017 criteria in our study is somewhat lower. This is probably due to our study design by taking CDMS, a more clinical primary endpoint instead of new T2 lesions on a second MRI. We identified a minor subgroup of 7 patients who were responsible for the loss in specificity and who had an FU duration of 2.3 years. New lesions on subsequent MRI were observed in 4 of these patients. The other 3 patients did not undergo a second MRI. However, given the presence of typical MS lesions at baseline and $\mathrm{OCB}$ positivity in these 3 patients, it is quite likely that these patients would also have developed new MRI lesions after a longer FU. Taken together, we believe that initiation of DMT based on the novel criteria is warranted. Yet, clinicians should be aware that with the McDonald 2017 criteria, more patients will be identified at baseline and that a proportion of these patients will clinically have a less active disease course.

Performing spinal MRI led to fulfillment of the McDonald 2017 criteria at baseline in 3/41 (7\%) patients with CDMS, but did not have additional value in the McDonald 2010 criteria, in line with another study that indicated limited value of spinal cord imaging in the McDonald 2010 criteria in children. ${ }^{6}$ Fadda et al. ${ }^{15}$ argued whether spinal cord acquisition would meaningfully add to the performance of the McDonald 2017 criteria because only a real small proportion of their patients fulfilled the criteria based on spinal cord MRI. However, in our cohort, $7 \%$ of the patients with CDMS could have been identified at baseline, which could significantly reduce the time to diagnosis in these patients. The exact place of spinal cord imaging as part of the MS diagnostic procedure deserves further investigation.

Our data show that approximately $10 \%$ of the patients with ADEM fulfill the McDonald 2010 and 2017 criteria at baseline. However, no patient with ADEM was diagnosed with CDMS in our cohort. The IPMSSG 2012 criteria explicitly mention not to apply the McDonald 2010 criteria to patients with ADEM. Our data support this view for the McDonald 2017 criteria to prevent the incorrect initiation of treatment in these monophasic patients.
Regarding age, ADS- patients aged $<12$ years seemed to have better accuracy for the McDonald 2017 criteria than the total group (sensitivity $100 \%$ vs $90 \%$, specificity $81 \%$ vs $60 \%$, PPV both $64 \%$, NPV $100 \%$ vs $89 \%$ ), despite the small sample size for this analysis. This implies that both the McDonald 2010 criteria and McDonald 2017 criteria can be used across the age span, including children aged $<12$ years with ADS, excluding patients with ADEM, in keeping with the results from previous studies. $^{12,15,27}$

Our study has several limitations. The choice of brain and/or spinal MRI, inclusion of contrast or not, and the decision to include testing for CSF OSBs were left to the discretion of the treating physician. For example, spinal imaging is not always justified (sedation may be needed), CSF is not always tested in isolated optic neuritis, and a paired serum sample is not always available with CSF (e.g., in the case of exclusion of suspected infection). Therefore, similar to other studies on the diagnostic criteria for pediatric MS, there was not complete coverage of all potentially relevant parameters. However, our main goal was to evaluate the revised 2017 criteria in real-world data; therefore, we did not exclude patients from the analyses. Instead, a few subanalyses have been performed. Despite our considerable FU duration of median 4.6 years, it is possible that some patients may develop a second attack in the future. DMT could have postponed CDMS diagnosis; however, our subanalysis excluding these patients showed no differences in test characteristics. Second, the PROUD-kids study did not have a standardized MRI FU; therefore, we did not take FU MRIs into account for the analysis of the 2010 and 2017 criteria. However, the scope of this article was to analyze the diagnostic accuracy for CDMS at the first attack of ADS.

Our data suggest that the McDonald 2017 criteria perform well in children. MS diagnosis can be made earlier and leads to a higher number of patients with MS at baseline. Both the McDonald 2010 and 2017 criteria show similar results for the patients aged $<12$ years presenting with ADS and can therefore be applied in this population as well. As proposed by the IPMSSG for the McDonald 2010 criteria, application of both 2010 and 2017 criteria in patients with ADEM should be avoided.

\section{Acknowledgment}

The authors thank all the children and their families who participated in the Dutch PROUD-kids study for acquired demyelinating syndromes in children.

\section{Study funding}

The study was supported by the Dutch MS Research Foundation. This study was not industry sponsored.

\section{Disclosure}

Y.Y.M. Wong, C.L. de Mol, R.M. van der Vuurst de Vries, E.D. van Pelt, and I.A. Ketelslegers report no disclosures. C.E. Catsman-Berrevoets received travel funding from the European 
Paediatric Neurology Society. R.F. Neuteboom served on the scientific advisory board of LAREB and data safety monitory board of the EXCEL study. R.Q. Hintzen participated in trials with Biogen Idec, Merck Serono, Roche, and Novartis and is on the editorial board of Multiple Sclerosis and Related Disorders. Full disclosure form information provided by the authors is available with the full text of this article at Neurology.org/NN.

\section{Publication history}

Received by Neurology: Neuroimmunology \& Neuroinflammation August 20, 2018. Accepted in final form October 23, 2018.

\section{References}

1. Compston A, Coles A. Multiple sclerosis. Lancet 2008;372:1502-1517.

2. Venkateswaran S, Banwell B. Pediatric multiple sclerosis. Neurologist 2010;16: 92-105.

3. Waldman A, Ghezzi A, Bar-Or A, Mikaeloff Y, Tardieu M, Banwell B. Multiple sclerosis in children: an update on clinical diagnosis, therapeutic strategies, and research. Lancet Neurol 2014;13:936-948.

4. Polman CH, Reingold SC, Banwell B, et al. Diagnostic criteria for multiple sclerosis: 2010 revisions to the McDonald criteria. Ann Neurol 2011;69:292-302.

5. Thompson AJ, Banwell BL, Barkhof F, et al. Diagnosis of multiple sclerosis: 2017 revisions of the McDonald criteria. Lancet Neurol 2018;17:162-173.

6. Hummel HM, Bruck W, Dreha-Kulaczewski S, Gartner J, Wuerfel J. Pediatric onset multiple sclerosis: McDonald criteria 2010 and the contribution of spinal cord MRI. Mult Scler 2013;19:1330-1335.

7. Kornek B, Schmitl B, Vass K, et al. Evaluation of the 2010 McDonald multiple sclerosis criteria in children with a clinically isolated syndrome. Mult Scler 2012;18 $1768-1774$.

8. Sadaka Y, Verhey LH, Shroff MM, et al. McDonald criteria for diagnosing pediatric multiple sclerosis. Ann Neurol 2012;72:211-223.

9. Sedani S, Lim MJ, Hemingway C, Wassmer E, Absoud M. Paediatric multiple sclerosis: examining utility of the McDonald 2010 criteria. Mult Scler 2012;18: 679-682.

10. Tantsis EM, Prelog K, Brilot F, Dale RC. Risk of multiple sclerosis after a first demyelinating syndrome in an Australian Paediatric cohort: clinical, radiological features and application of the McDonald 2010 MRI criteria. Mult Scler 2013;19: 1749-1759.

11. Williams MT, Tapos DO, Juhasz C. Use of the $2010 \mathrm{McDonald}$ criteria can facilitate early diagnosis of pediatric multiple sclerosis in a predominantly black cohort. Pediatr Neurol 2014;51:826-830.

12. van Pelt ED, Neuteboom RF, Ketelslegers IA, Boon M, Catsman-Berrevoets CE, Hintzen RQ. Application of the 2012 revised diagnostic definitions for paediatric multiple sclerosis and immune-mediated central nervous system demyelination disorders. J Neurol Neurosurg Psychiatry 2014;85:790-794.

13. Krupp LB, Tardieu M, Amato MP, et al. International Pediatric Multiple Sclerosis Study group criteria for pediatric multiple sclerosis and immune-mediated central nervous system demyelinating disorders: revisions to the 2007 definitions. Mult Scler 2013;19:1261-1267.

14. Hintzen RQ, Dale RC, Neuteboom RF, Mar S, Banwell B. Pediatric acquired CNS demyelinating syndromes: features associated with multiple sclerosis. Neurology 2016;87:S67-S73.

15. Fadda G, Brown RA, Longoni G, et al. MRI and laboratory features and the performance of international criteria in the diagnosis of multiple sclerosis in children and adolescents: a prospective cohort study. Lancet Child Adolesc Health 2018;2:191-204.

16. de Mol CL, Wong YYM, van Pelt ED, et al. Incidence and outcome of acquired demyelinating syndromes in Dutch children: update of a nationwide and prospective study. J Neurol 2018;265:1310-1319.

17. Ketelslegers IA, Catsman-Berrevoets CE, Neuteboom RF, et al. Incidence of acquired demyelinating syndromes of the CNS in Dutch children: a nationwide study. J Neurol 2012;259:1929-1935.

18. van der Vuurst de Vries RM, van Pelt ED, Mescheriakova JY, et al. Disease course after clinically isolated syndrome in children versus adults: a prospective cohort study. Eur J Neurol 2017;24:315-321.

19. Dale RC, Brilot F, Banwell B. Pediatric central nervous system inflammatory demyelination: acute disseminated encephalomyelitis, clinically isolated syndromes, neuromyelitis optica, and multiple sclerosis. Curr Opin Neurol 2009;22: 233-240.

20. Banwell B, Bar-Or A, Arnold DL, et al. Clinical, environmental, and genetic determinants of multiple sclerosis in children with acute demyelination: a prospective national cohort study. Lancet Neurol 2011;10:436-445.

21. Mikaeloff Y, Suissa S, Vallée L, et al. First episode of acute CNS inflammatory demyelination in childhood: prognostic factors for multiple sclerosis and disability. J Pediatr 2004;144:246-252.

22. Hacohen Y, Wong YY, Lechner C, et al. Disease course and treatment responses in children with relapsing myelin oligodendrocyte glycoprotein antibody-associated disease. JAMA Neurol 2018;75:478-487.

23. Hennes EM, Baumann M, Schanda K, et al. Prognostic relevance of MOG antibodies in children with an acquired demyelinating syndrome. Neurology 2017;89: 900-908.

24. Schumacher GA, Beebe G, Kibler RF, et al. Problems of experimental trials of therapy in multiple sclerosis: report by the panel on the evaluation of experimental trials of therapy in multiple sclerosis. Ann N Y Acad Sci 1965;122:552-568.

25. Freedman MS, Thompson EJ, Deisenhammer F, et al. Recommended standard of cerebrospinal fluid analysis in the diagnosis of multiple sclerosis: a consensus statement. Arch Neurol 2005;62:865-870.

26. Ghezzi A, Amato MP, Makhani N, Shreiner T, Gärtner J, Tenembaum S. Pediatric multiple sclerosis: conventional first-line treatment and general management. Neurology 2016;87:S97-S102.

27. Hacohen Y, Mankad K, Chong WK, et al. Diagnostic algorithm for relapsing acquired demyelinating syndromes in children. Neurology 2017;89:269-278. 
Appendix 1 Author contributions

\begin{tabular}{|c|c|c|c|c|}
\hline Name & Degrees & Location & Role & Contribution \\
\hline Yu Yi M. Wong & MD & $\begin{array}{l}\text { Department of Neurology, MS Centre } \\
\text { ErasMS, Erasmus MC, Rotterdam, The } \\
\text { Netherlands }\end{array}$ & First author & $\begin{array}{l}\text { Study design, acquisition of data, statistical analysis, } \\
\text { interpretation of data, and drafting of the } \\
\text { manuscript }\end{array}$ \\
\hline C. Louk de Mol & $\mathrm{BSC}$ & $\begin{array}{l}\text { Department of Neurology, MS Centre } \\
\text { ErasMS, Erasmus MC, Rotterdam, The } \\
\text { Netherlands }\end{array}$ & Coauthor & $\begin{array}{l}\text { Study design, acquisition of data, statistical analysis, } \\
\text { interpretation of data, and drafting of manuscript }\end{array}$ \\
\hline $\begin{array}{l}\text { Roos M. van der Vuurst } \\
\text { de Vries }\end{array}$ & MD & $\begin{array}{l}\text { Department of Neurology, MS Centre } \\
\text { ErasMS, Erasmus MC, Rotterdam, The } \\
\text { Netherlands }\end{array}$ & Coauthor & $\begin{array}{l}\text { Interpretation of data and revision of the manuscript } \\
\text { for content }\end{array}$ \\
\hline E. Daniëlle van Pelt & $\mathrm{MD}, \mathrm{PhD}$ & $\begin{array}{l}\text { Department of Neurology, MS Centre } \\
\text { ErasMS, Erasmus MC, Rotterdam, The } \\
\text { Netherlands }\end{array}$ & Co-author & $\begin{array}{l}\text { Acquisition of data and revision of the manuscript } \\
\text { for content }\end{array}$ \\
\hline Immy A. Ketelslegers & $\mathrm{MD}, \mathrm{PhD}$ & $\begin{array}{l}\text { Department of Neurology, MS Centre } \\
\text { ErasMS, Erasmus MC, Rotterdam, The } \\
\text { Netherlands }\end{array}$ & Coauthor & $\begin{array}{l}\text { Acquisition of data and revision of the manuscript } \\
\text { for content }\end{array}$ \\
\hline $\begin{array}{l}\text { Coriene E. Catsman- } \\
\text { Berrevoets }\end{array}$ & $\mathrm{MD}, \mathrm{PhD}$ & $\begin{array}{l}\text { Department of Pediatric Neurology, } \\
\text { Erasmus MC, Rotterdam, The } \\
\text { Netherlands }\end{array}$ & Coauthor & $\begin{array}{l}\text { Acquisition of data, revision of manuscript for } \\
\text { content }\end{array}$ \\
\hline Rinze F. Neuteboom & $\mathrm{MD}, \mathrm{PhD}$ & $\begin{array}{l}\text { Department of Pediatric Neurology, } \\
\text { Erasmus MC, Rotterdam, The } \\
\text { Netherlands }\end{array}$ & Last author & $\begin{array}{l}\text { Study design, study supervision, acquisition of data, } \\
\text { interpretation of data, and revision of the } \\
\text { manuscript for content }\end{array}$ \\
\hline Rogier Q. Hintzen & $\mathrm{MD}, \mathrm{PhD}$ & $\begin{array}{l}\text { Department of Neurology, MS Centre } \\
\text { ErasMS, Erasmus MC, Rotterdam, The } \\
\text { Netherlands }\end{array}$ & $\begin{array}{l}\text { Last author, } \\
\text { corresponding } \\
\text { author }\end{array}$ & $\begin{array}{l}\text { Study design, study supervision, interpretation of } \\
\text { data, and revision of the manuscript for content }\end{array}$ \\
\hline
\end{tabular}


Appendix 2 Coinvestigators

\begin{tabular}{|c|c|c|c|c|}
\hline Name & Degrees & Location & Role & Contribution \\
\hline D.P. Bakker & $\mathrm{MD}, \mathrm{PhD}$ & $\begin{array}{l}\text { Departments of Pediatric Neurology, VU Medical Centre, } \\
\text { Amsterdam }\end{array}$ & Coinvestigator & Collection of data \\
\hline M. Boon & $\mathrm{MD}, \mathrm{PhD}$ & Department of Pediatric Neurology, UMCG, Groningen & Coinvestigator & Collection of data \\
\hline K.P.J. Braun & $\mathrm{MD}, \mathrm{PhD}$ & $\begin{array}{l}\text { Department of Pediatric Neurology, University Medical } \\
\text { Centre Utrecht, Utrecht }\end{array}$ & Coinvestigator & Collection of data \\
\hline K.G.J. van Dijk & $\mathrm{MD}, \mathrm{PhD}$ & Department of Pediatrics, Rijnstate Hospital, Arnhem & Coinvestigator & Collection of data \\
\hline M.J. Eikelenboom & $\mathrm{MD}, \mathrm{PhD}$ & Department of Neurology, Westfriesgasthuis, Hoorn & Coinvestigator & Collection of data \\
\hline M. Engelen & $\mathrm{MD}, \mathrm{PhD}$ & $\begin{array}{l}\text { Department of Pediatric Neurology, Academic Medical } \\
\text { Centre Amsterdam, Amsterdam }\end{array}$ & Coinvestigator & Collection of data \\
\hline K. Geleijns & $\mathrm{MD}, \mathrm{PhD}$ & $\begin{array}{l}\text { Department of Pediatric Neurology, University Medical } \\
\text { Centre Utrecht, Utrecht }\end{array}$ & Coinvestigator & Collection of data \\
\hline C.A. Haaxma & $\mathrm{MD}, \mathrm{PhD}$ & $\begin{array}{l}\text { Department of Pediatric Neurology, Radboud UMC, } \\
\text { Nijmegen }\end{array}$ & Coinvestigator & Collection of data \\
\hline J.M.F. Niermeijer & $\mathrm{MD}, \mathrm{PhD}$ & $\begin{array}{l}\text { Department of Neurology, Elisabeth-Tweesteden } \\
\text { Hospital, Tilburg }\end{array}$ & Coinvestigator & Collection of data \\
\hline E.H. Niks & $\mathrm{MD}, \mathrm{PhD}$ & $\begin{array}{l}\text { Department of Neurology, Leiden University Medical } \\
\text { Centre, Leiden }\end{array}$ & Coinvestigator & Collection of data \\
\hline C.M.P.C.D. Peeters-Scholte & $\mathrm{MD}, \mathrm{PhD}$ & $\begin{array}{l}\text { Department of Neurology, Leiden University Medical } \\
\text { centre, Leiden }\end{array}$ & Coinvestigator & Collection of data \\
\hline E.A.J. Peeters & $\mathrm{MD}, \mathrm{PhD}$ & $\begin{array}{l}\text { Department of Neuropediatrics, Haga Hospital, the } \\
\text { Hague }\end{array}$ & Coinvestigator & Collection of data \\
\hline B.T. Poll & $\mathrm{MD}, \mathrm{PhD}$ & $\begin{array}{l}\text { The Department of Pediatric Neurology, Emma } \\
\text { Children's Hospital/AMC, Amsterdam }\end{array}$ & Coinvestigator & Collection of data \\
\hline R.P. Portier & MD & $\begin{array}{l}\text { Department of Neurology, Medisch Spectrum Twente, } \\
\text { Enschede }\end{array}$ & Coinvestigator & Collection of data \\
\hline J.F. de Rijk-van Andel & $\mathrm{MD}, \mathrm{PhD}$ & Department of Neurology, Amphia Hospital, Breda & Coinvestigator & Collection of data \\
\hline J.P.A. Samijn & $\mathrm{MD}, \mathrm{PhD}$ & $\begin{array}{l}\text { Department of Neurology, Maasstad Hospital, } \\
\text { Rotterdam }\end{array}$ & Coinvestigator & Collection of data \\
\hline H.M. Schippers & MD & $\begin{array}{l}\text { Department of Neurology, St. Antonius Hospital, } \\
\text { Nieuwegein }\end{array}$ & Coinvestigator & Collection of data \\
\hline I.N. Snoeck & MD & $\begin{array}{l}\text { Department of Neuropediatrics, Haga Hospital, the } \\
\text { Hague }\end{array}$ & Coinvestigator & Collection of data \\
\hline H. Stroink & $\mathrm{MD}, \mathrm{PhD}$ & $\begin{array}{l}\text { Department of Neurology, Canisius-Wilhelmina Hospital, } \\
\text { Nijmegen }\end{array}$ & Coinvestigator & Collection of data \\
\hline R.J. Vermeulen & $\mathrm{MD}, \mathrm{PhD}$ & $\begin{array}{l}\text { Department of Pediatric Neurology, Maastricht UMC, } \\
\text { Maastricht }\end{array}$ & Coinvestigator & Collection of data \\
\hline A. Verrips & $\mathrm{MD}, \mathrm{PhD}$ & $\begin{array}{l}\text { Department of Neurology, Canisius-Wilhelmina Hospital, } \\
\text { Nijmegen }\end{array}$ & Coinvestigator & Collection of data \\
\hline F. Visscher & MD & $\begin{array}{l}\text { Department of Pediatric Neurology, Admiraal de Ruyter } \\
\text { Hospital, Goes }\end{array}$ & Coinvestigator & Collection of data \\
\hline J.H.S. Vles & $\mathrm{MD}, \mathrm{PhD}$ & $\begin{array}{l}\text { Department of Pediatric Neurology, Maastricht UMC, } \\
\text { Maastricht }\end{array}$ & Coinvestigator & Collection of data \\
\hline M.A.A.P. Willemsen & $\mathrm{MD}, \mathrm{PhD}$ & $\begin{array}{l}\text { Department of Pediatric Neurology, Radboud UMC, } \\
\text { Nijmegen }\end{array}$ & Coinvestigator & Collection of data \\
\hline
\end{tabular}




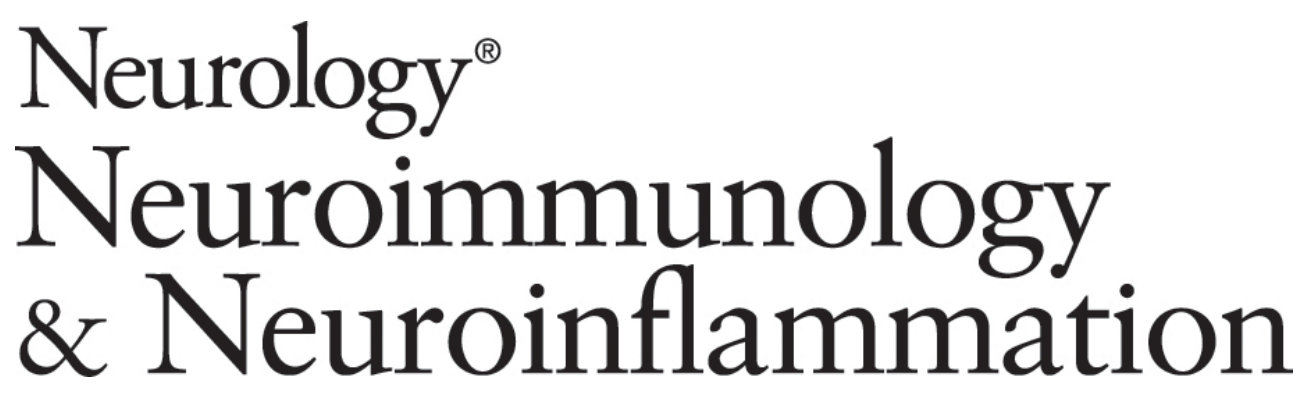

Real-world validation of the 2017 McDonald criteria for pediatric MS Yu Yi M. Wong, C. Louk de Mol, Roos M. van der Vuurst de Vries, et al. Neurol Neuroimmunol Neuroinflamm 2019;6; DOI 10.1212/NXI.0000000000000528

This information is current as of December 17, 2018

Neurol Neuroimmunol Neuroinflamm is an official journal of the American Academy of Neurology. Published since April 2014, it is an open-access, online-only, continuous publication journal. Copyright Copyright $\odot 2018$ The Author(s). Published by Wolters Kluwer Health, Inc. on behalf of the American Academy of Neurology.. All rights reserved. Online ISSN: 2332-7812.

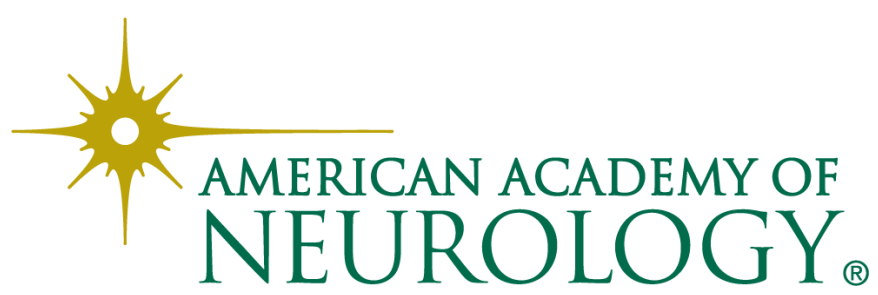




\section{Updated Information \& Services}

References

Citations

Subspecialty Collections

Permissions \& Licensing

Reprints including high resolution figures, can be found at: http://nn.neurology.org/content/6/2/e528.full.html

This article cites 27 articles, 1 of which you can access for free at: http://nn.neurology.org/content/6/2/e528.full.html\#\#ref-list-1

This article has been cited by 1 HighWire-hosted articles: http://nn.neurology.org/content/6/2/e528.full.html\#\#otherarticles

This article, along with others on similar topics, appears in the following collection(s):

All Demyelinating disease (CNS)

http://nn.neurology.org//cgi/collection/all_demyelinating_disease_cns All Pediatric

http://nn.neurology.org//cgi/collection/all_pediatric

MRI

http://nn.neurology.org//cgi/collection/mri

Multiple sclerosis

http://nn.neurology.org//cgi/collection/multiple_sclerosis

Information about reproducing this article in parts (figures,tables) or in its entirety can be found online at:

http://nn.neurology.org/misc/about.xhtml\#permissions

Information about ordering reprints can be found online:

http://nn.neurology.org/misc/addir.xhtml\#reprintsus

Neurol Neuroimmunol Neuroinflamm is an official journal of the American Academy of Neurology.

Published since April 2014, it is an open-access, online-only, continuous publication journal. Copyright

Copyright $\odot 2018$ The Author(s). Published by Wolters Kluwer Health, Inc. on behalf of the American

Academy of Neurology.. All rights reserved. Online ISSN: 2332-7812.

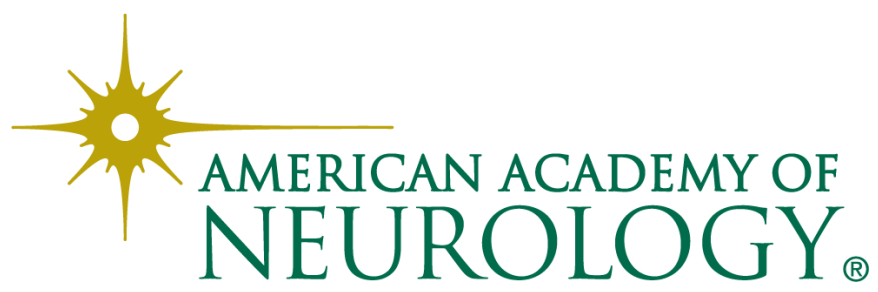

